\title{
Photoelectric and Electrical Properties of Composite Materials Based on $n$-InSe and Graphite
}

\author{
V.M. Kaminskiii ${ }^{1}$, V.B. Boledzyuk ${ }^{1, *}$, V.M. Vodopyanov ${ }^{1}$, P.I. Savitskii ${ }^{1}$, A.V. Zaslonkin ${ }^{1}$, \\ M.V. Zapolovskyi ${ }^{2}$ \\ ${ }^{1}$ Frantsevych Institute for Problems of Materials Science of National Academy of Sciences of Ukraine, Chernivtsi \\ Branch, 5, I. Vilde St., 58001 Chernivtsi, Ukraine \\ 2 Yuriy Fedkovych Chernivtsi National University, 2, Kotsyubynsky St., 58012 Chernivtsi, Ukraine
}

(Received 21 March 2021; revised manuscript received 09 August 2021; published online 20 August 2021)

\begin{abstract}
This paper presents the results of research of composite materials and structures made on the basis of layered semiconductors and graphite. These materials have a similar crystalline structure and due to their unique physical properties are promising for electronics and photoelectronics. Therefore, the idea of making new composite materials and structures based on them is quite obvious. We have tried to take some steps in this direction using various technological operations. Three types of samples were prepared: pressed tablets of mixed powders of InSe and thermoexpanded graphite; graphite films from aqueous suspension of thermoexpanded graphite, which were deposited onto fresh cleavage InSe (0001) surface, and graphite/InSe structures obtained by vacuum deposition. Their photoelectric and electrical properties have been investigated. A significant increase in the electrical conductivity of InSe-thermoexpanded graphite composite material relative to the initial InSe powder has been found. This means that in this material an electric current flows through the channels formed by graphite, and the selected pressure at which the samples were prepared provides good contact between individual crystallites. The photosensitivity of the obtained materials and structures is determined by the optical properties of InSe. The photosensitivity range of InSe-thermoexpanded graphite composite material is smaller than that of InSe or structures due to scattering at grain boundaries.
\end{abstract}

Keywords: Indium selenide, Thermoexpanded graphite, Composite material, Photosensitivity, Electrical conductivity.

\section{INTRODUCTION}

The intensive development of technologies imposes new requirements on the properties of electrically conductive composite materials, which requires changes in their composition and searching for new methods for their production. Carbon composite materials make it possible to create a variety of electronic devices based on them [1]. In particular, by alternating $s p^{2}$ and $s p^{3}$ domains of micro- and nanometer sizes, layered compositions of metal-insulator-metal or metal-insulatorsemiconductor suitable for use in photosensitive devices can be obtained [2,3].

Thermoexpanded graphite (TEG) is a promising material for creating new composite materials. It is chemically inert, heat-resistant and has a sufficiently high electrical conductivity of the order of $10^{3} \mathrm{Ohm}^{-1} \mathrm{~cm}^{-1}$. An important difference between TEG and other powdered carbon materials is its ability to be compressed without the use of binders [4]. The chemical and thermal stability in combination with controlled electrical and thermal conductivity, high porosity and high internal specific surface create the preconditions for the development of multifunctional materials.

The crystal structure of TEG $[5,6]$ is similar to that of $\mathrm{A}^{3} \mathrm{~B}^{6}$ layered compounds (InSe, GaSe), which due to their unique physical properties are of considerable interest for nanoelectronics and optoelectronics [7]. In our opinion, the creation of new multifunctional materials by coupling TEG and layered crystals in one com- posite material is an interesting and promising task. On the one hand, this allows to control the value of the electrical conductivity due to the different TEG content, and, on the other hand, to exploit the optical properties of layered crystals. The first steps in this direction were done in [8], where a simple technology of a low-cost photosensitive sensor was proposed based on GaSe-graphite composite material. In the present work, we develop this idea and investigate the physical properties of a composite material based on InSe and TEG. For comparison, the results of research of graphite/InSe structures are also presented.

\section{EXPERIMENTAL}

Indium selenide single crystals were grown by the Bridgman method from a melt of non-stoichiometric composition $\mathrm{In}_{1.03} \mathrm{Se}_{0.97}$. They had $n$-type conductivity with an electron concentration of the order of $10^{15} \mathrm{~cm}^{-3}$ at room temperature. InSe single crystals crystallize into a structure of $\gamma$-polytype with a point group of $C^{5} 3 v$. The measured parameters of the unit cell are $a=4.003 \pm 0.001 \AA$ and $c=24.9553 \pm 0.0006 \AA$ in the hexagonal description.

Thin plates of InSe with typical dimensions of $5 \times 5 \times 1 \mathrm{~mm}^{3}$ (substrates), InSe powder obtained from InSe single crystals with a dispersion of less than $75 \mu \mathrm{m}$ and TEG were used as initial materials. The mechanically ground InSe powder and TEG were filled with distilled water and sonicated for $10 \mathrm{~min}$ in an

\footnotetext{
*boledvol@gmail.com
} 
UZDN-A ultrasonic disperser to reduce the grain size.

Three types of samples were prepared: InSe-TEG composite material; graphite films obtained from an aqueous suspension of TEG, and graphite/InSe structures obtained by vacuum deposition.

InSe-TEG composite material was prepared from InSe and TEG powders smaller than $75 \mu \mathrm{m}$. The powders were mixed for $30 \mathrm{~min}$ to obtain a homogeneous mixture and compressed into disks at a pressure of $20 \mathrm{MPa}$. The samples with 10 and 20 wt. \% TEG were prepared.

Graphite films were obtained by deposition of an aqueous suspension of TEG onto fresh cleavage InSe (0001) surface.

Graphite structures were grown on the InSe substrates by vacuum deposition at $10^{-4} \mathrm{~Pa}$. Carbon was sputtered from an electrode under a voltage of $2.8 \mathrm{kV}$ at $390^{\circ} \mathrm{C}$. Electron beam sputtering allows to evaporate refractory metals and carbon, which have a high melting point. Low values of the specific surface energy of the van der Waals surface and DC voltage applied to the substrate provide the formation of critical nuclei of carbon nanostructures on the (0001) surface.

The electrical conductivity was measured in DC mode. Photosensitivity spectra were investigated by means of a monochromator MDR-3 at modulated light flux.

\section{RESULTS AND DISCUSSION}

Fig. 1 shows the spectral distribution of photosensitivity of the InSe single crystal (a, curve 1), graphite film obtained from a suspension (a, curve 2) and graphite/InSe structure obtained by vacuum deposition (b). All samples are photosensitive in the energy range of $h v=1.2 \div 2.6 \mathrm{eV}$. There is an exciton peak at $E_{e x}=1.23 \mathrm{eV}$ in the InSe single crystal, which is observed only in high-quality layered semiconductors [9]. The photosensitivity increases sharply at $h v \approx 1.2 \mathrm{eV}$ due to fundamental absorption in InSe $\left(E_{g}=1.26 \mathrm{eV}\right)$. A further increase in the photosensitivity with increasing photon energy is due to an increase in the light absorption coefficient of InSe. The decrease in the photosensitivity of InSe at high photon energies is due to an increase in recombination in the near-surface layer of the semiconductor. Growth of the absorption coefficient leads to light absorption in a thin near-surface layer. This causes an increase in the concentration of nonequilibrium charge carriers that increases recombination in this layer. Accordingly, carriers do not have time to diffuse into the bulk of the semiconductor and the photosensitivity decreases.

For the graphite/InSe structure (Fig. 1b), an increase in photon energy leads to an increase in the photosensitivity with a maximum at $h v \approx 2.5 \mathrm{eV}$. Investigation of carbon nanoformations grown on the InSe surface by this technology shows the presence of a large number of structural defects [10]. At a height up to $100 \mathrm{~nm}$, such nanostructures are transparent in the region of fundamental absorption of InSe. We assume that the maximum photosensitivity is determined by absorption in a thin layer of $\operatorname{In}_{2} \mathrm{Se}_{3}$, which is formed on the InSe surface at heating $[11,12]$. It was shown in [13] that the band gap of $a$ - $\operatorname{In}_{2} \mathrm{Se}_{3}$ films increases with decreasing thickness and can reach $2.8 \mathrm{eV}$ for $3.1 \mathrm{~nm}$.
Based on this, we assume that the InSe substrate is strongly heated during vacuum deposition and several upper layers change their phase composition.
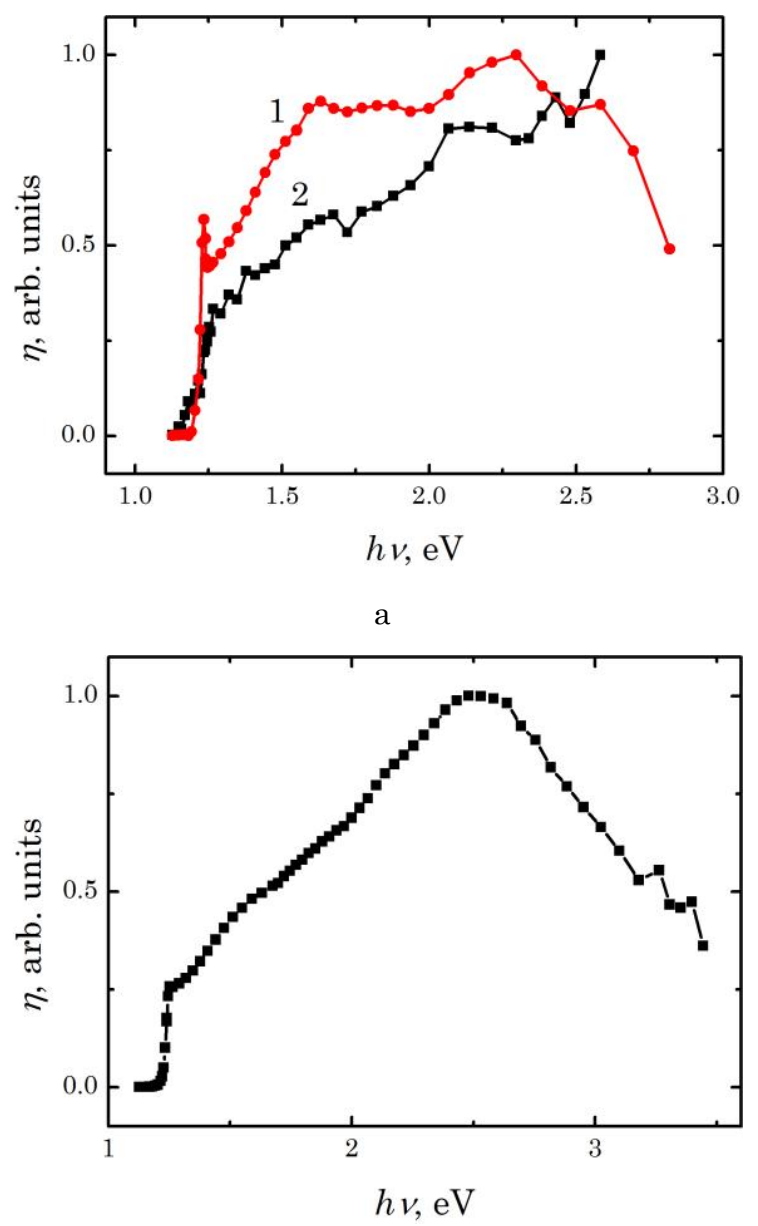

$\mathrm{b}$

Fig. 1 - Spectral distribution of photosensitivity of $n$-InSe (a, curve 1), graphite film obtained from suspension (a, curve 2) and graphite/InSe structure (b)

Fig. 2 shows the spectral distribution of photosensitivity of InSe-TEG (10 wt. \% TEG) with a maximum in the fundamental absorption edge region of InSe. The fundamental absorption edge is blurred compared to $n$ InSe/graphite structures due to absorption at the grain boundaries. This also causes a further decrease in the photosensitivity. There is a high concentration of defects that act as trapping and recombination centers for photogenerated electrons at the grain boundaries. Electrons captured by such centers do not participate in the photocurrent. The absolute value of the photocurrent of the InSe-TEG is much smaller than that of graphite/ InSe structures.

Photosensitive graphite/GaSe structures were also obtained by vacuum deposition. Fig. 3 shows the spectral distribution of photosensitivity of such structures. It is shown that the photosensitivity increases sharply at the fundamental absorption edge $\left(E_{g} \approx 2.0 \mathrm{eV}\right)$ due to photogenerated electrons from the valence band. The photosensitivity increases with increasing photon energy in the studied range of energies. 


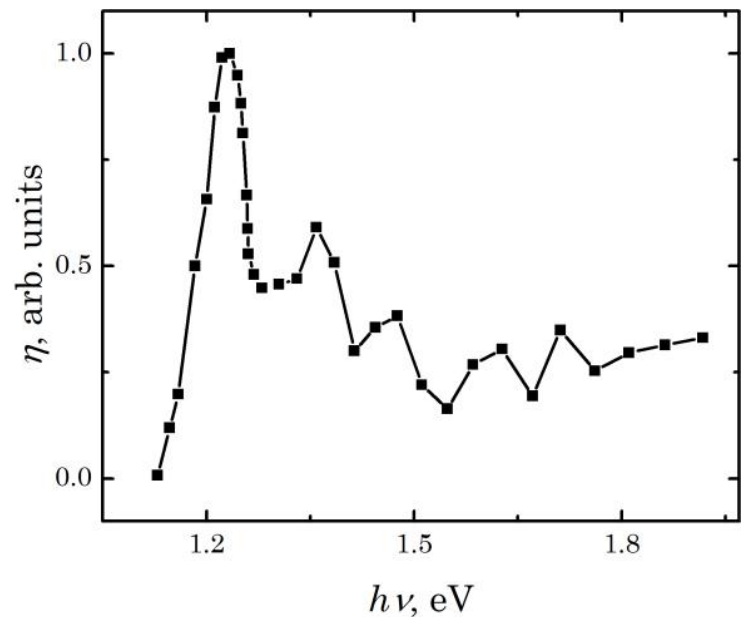

Fig. 2 - Spectral distribution of photosensitivity of InSe-TEG (10 wt. \% TEG) composite material

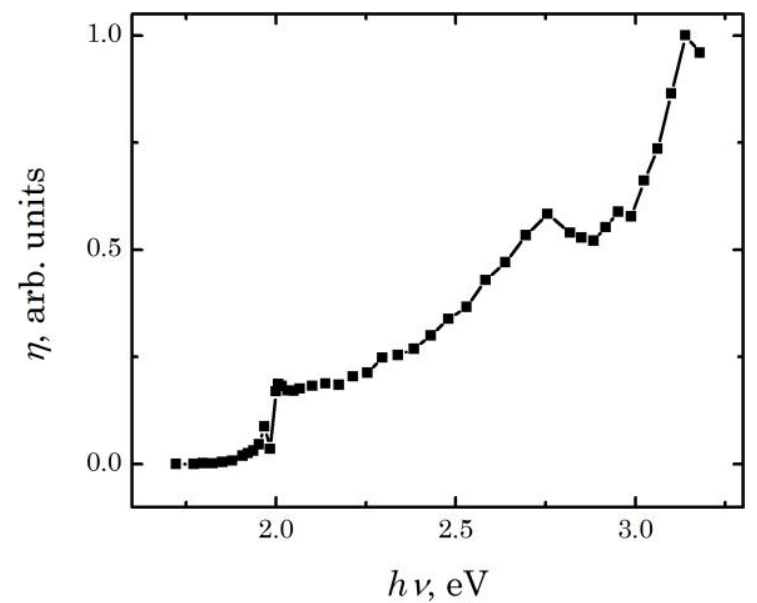

Fig. 3 - Spectral distribution of photosensitivity of graphite/ GaSe structure

Table 1 - Specific electrical conductivity of InSe powder, TEG and InSe-TEG

\begin{tabular}{|c|c|c|c|}
\hline & type & $T, \mathbf{K}$ & $\sigma, \mathrm{Ohm}^{-1} \mathrm{~cm}^{-1}$ \\
\hline InSe powder & $n$ & $\begin{array}{l}200 \\
285\end{array}$ & $\begin{array}{l}4.9 \cdot 10^{-9} \\
1.2 \cdot 10^{-7}\end{array}$ \\
\hline TEG & $n$ & $\begin{array}{c}80 \\
285 \\
\end{array}$ & $\begin{array}{c}924 \\
1220 \\
\end{array}$ \\
\hline $\begin{array}{l}\text { InSe-TEG } \\
(10 \text { wt. \% TEG) }\end{array}$ & $n$ & $\begin{array}{c}80 \\
285 \\
\end{array}$ & $\begin{array}{c}74 \\
110 \\
\end{array}$ \\
\hline $\begin{array}{l}\text { InSe-TEG } \\
(20 \text { wt. \% TEG) }\end{array}$ & $n$ & 285 & 260 \\
\hline
\end{tabular}

The values of electrical conductivity $(\sigma)$ of the initial and InSe-TEG composite materials measured at different temperatures are shown in Table 1. The materials have $n$-type conductivity. The growth of $\sigma$ with increasing temperature is found. As can be seen from Table 1, at $T=285 \mathrm{~K}, \sigma>10^{3} \mathrm{Ohm}^{-1} \mathrm{~cm}^{-1}$ for TEG and for InSe powder $\sigma \approx 1.2 \cdot 10^{-7} \mathrm{Ohm}^{-1} \mathrm{~cm}^{-1}$. Graphite leads to an increase in the electrical conductivity of the composite material by 9 orders of magnitude. The conductivity of InSe-TEG has a percolation character. The charge transfer is carried out through the conductive channels formed by contacting graphite crystallites. Note also that the flow of current between crystallites located at some distance from each other can occur due to tunneling of electrons across the grain boundaries. Based on the data in Table 1, it can be assumed that the percolation threshold for InSe-TEG data is less than $10 \mathrm{wt} . \%$. For comparison, the percolation threshold in a conjugated polymer-carbon nanotube is 8.4 wt. \% [14].

The electrical conductivity of InSe-TEG composite is determined by the electrical conductivity of individual TEG and InSe crystallites, as well as the conductivity along grain boundaries. The temperature dependence of the electrical conductivity is largely determined by the scattering mechanisms of charge carriers. It is known that the main mechanism in InSe single crystals and graphite is scattering by optical phonons $[15,16]$. Since the free path of electrons in InSe is much smaller than the size of individual crystallites $(<75 \mu \mathrm{m})$, the main scattering mechanisms in InSe-TEG are scattering by optical phonons (inside the crystallites) and scattering at grain boundaries. In addition, scattering by ionized impurities, neutral impurities, linear and planar defects are also possible.

The pressure at which InSe-TEG samples are compressed plays an important role. An increase in the pressure leads to an increase in the contact area and conductivity, but high pressure can lead to plastic deformation of the crystallites. Taking into account the dependence $\rho(p)$ for graphite [15], it can be assumed that a pressure of $20 \mathrm{MPa}$ provides good contact between particles (beyond the percolation threshold), but does not lead to their strong deformation.

\section{CONCLUSIONS}

The InSe-TEG composite material has been investigated. A comparison of its photosensitivity with those of graphite/InSe structures is performed. The electrical conductivity of the composite material is determined by the content ratio of TEG, and the photosensitivity is determined by absorption in InSe. An increase in the electrical conductivity of InSe-TEG in comparison with InSe powder (by 9 orders of magnitude) and InSe single crystal is found. The electrical conductivity of InSeTEG has a percolation character, and the percolation threshold is less than 10 wt. \%. InSe-TEG is photosensitive in the range of $1.2 \div 1.9 \mathrm{eV}$. InSe-TEG has less photosensitivity than graphite/InSe structures, but its advantage is a simple technology.

\section{REFERENCES}

1. M. Inagaki, New Carbons - Control of Structure and Functions (Amsterdam: Elsevier: 2000).

2. Q.Z. Xue, X. Zhang, Carbon 43 No 4, 760 (2005).

3. I. Lazar, G. Lazar, J. Non-Cryst. Solids $\mathbf{3 5 2}$ No 21, 2096 (2006).

4. Yu.I. Sementsov, S.L. Revo, K.O. Ivanenko, S. Hamamda,

Expanded Graphite and Its Composites (Kyiv: Akademperiodyka: 2019).

5. L.R. Radovic, Chemistry and Physics of Carbon (New York: Marcel Dekker: 2004).

6. G. Chen, D. Wu, W. Weng, C. Wu, Carbon 41 No 3, 619 (2003).

7. Z. Yang, J. Hao, Adv. Mat. Techn. 4 No 8, 1900108 (2019). 
8. V.V. Brus, P.D. Maryanchuk, Z.D. Kovalyuk, S.L. Abashyn, Nanotechnology 26 No 25, 255501 (2015).

9. O.Z. Alekperov, M.O. Godjaev, M.Z. Zarbaliev, R.A. Suleimanov, Sol. St. Commun. 77 No 1, 65 (1991).

10. V.M. Vodopyanov, I.G. Tkachuk, V.I. Ivanov, Z.R. Kudrynskyi, Z.D. Kovalyuk, J. Nano- Electron. Phys. 11 No 3, 03038 (2019).

11. O.A. Balitskii, R.V. Lutsiv, V.P. Savchyn, J.M. Stakhira, Mat. Sci. Eng. B 56 No 1, 5 (1998).

12. V. Savchyn, V. Kytsai, Th. Sol. Fil. 361-362, 123 (2000).
13. J. Quereda, R. Biele, G. Rubio-Bollinger, N. Agraï, R. D'Agosta, A. Castellanos-Gomez, Adv. Opt. Mat. 4 No 12, 1939 (2016).

14. J.N. Coleman, S. Curran, A.B. Dalton, A.P. Davey, B. McCarthy, W. Blau, R.C. Barklie, Phys. Rev. B 58 No 12, R7492(R) (1998).

15. I.V. Ovsiienko, L.Yu. Matzui, O.I. Prokopov, O.V. Zhuravkov, J. Nano- Electron. Phys. 8 No 2, 02017 (2016).

16. V.M. Kaminskii, Z.D. Kovalyuk, M.V. Tovarnitskii, V.I. Ivanov, M.V. Zapolovskyi, J. Phys. Stud. 24 No 3, 3704 (2020).

\title{
Фотоелектричні та електричні властивості композитних матеріалів на основі $n$-InSe і графіту
}

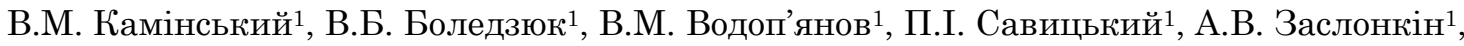 \\ М.В. Заполовський ${ }^{2}$
}

1 Чернівецьке відділення Інституту проблел матеріалознавства ілені I.М. Франиевича НАН Украӥни, вул. I. Вільде, 5, 58001 Чернівиі, Украӥна

2 Чернівецький національний університет ілені Ю. Федьковича, вул. М. Коцюбинського, 2, 58012 Чернівиі, Україна

\begin{abstract}
В роботі приведені результати досліджень композитних матеріалів та структур, виготовлених на основі шаруватих напівпровідників та графіту. Ці матеріали мають схожу кристалічну структуру та завдяки своїм унікальним фізичним властивостям е перспективними для електроніки та фотоелектроніки. Тому ідея виготовлення на їх основі нових композитів та структур е цілком очевидною. Ми намагалися зробити деякі кроки в цьому напрямку використовуючи різні технологічні операції. Було виготовлено три типи дослідних об’ектів: пресовані таблетки з порошків InSe та терморозширеного графіту; плівки із водної суспензії терморозширеного графіту, які наносились на свіжосколену поверхню (0001) InSe; структури графіт/InSe, одержані шляхом вакуумного напилення. Досліджено їх фотоелектричні та електричні властивості. Встановлено значне зростання електропровідності композитного матеріалу InSe-терморозширений графіт по відношенню до вихідного порошку InSe. Це означае, що в цьому матеріалі електричний струм протікае по каналах, утворених графітом, а вибраний тиск, при якому пресувались зразки, забезпечуе добрий контакт між окремими кристалітами. Фоточутливість отриманих матеріалів і структур визначаеться оптичними властивостями InSe. Діапазон фоточутливості композитного матеріалу InSe-терморозширений графіт є меншим ніж в InSe чи структурах графіт/InSe за рахунок розсіюванням на границях зерен.
\end{abstract}

Ключові слова: Селенід індію, Терморозширений графріт, Композитний матеріал, Фоточутливість, Електропровідність. 